\title{
Prevalence of anti-hepatitis $C$ antibodies and its co-infection with HIV in rural Cameroon
}

\author{
Valirie Ndip Agbor ${ }^{1 *} \mathbb{D}$, Claude Tayou Tagny ${ }^{1,2}$, Jules-Bertrand Kenmegne ${ }^{1,2}$, Bih Awazi $^{3}$, Charlotte Ngansop ${ }^{1,2}$, \\ Dora Mbanya ${ }^{1,2}$ and Nicaise Ndembi ${ }^{4}$
}

\begin{abstract}
Objective: To evaluate the prevalence of the co-infection between the human immunodeficiency virus (HIV) and hepatitis $\mathrm{C}$ virus $(\mathrm{HCV})$, and the prevalence of factors associated with $\mathrm{HCV}$ transmission in a rural Cameroonian community.

Results: The mean age of the 174 participants included in the study was 30.3 (standard deviation $=13.26$ ) years (age range 12-77 years). the prevalence of HCV/HIV co-infection was 1.7\% [95\% confidence interval (CI) 1.1-5.9]. The prevalence of HCV and HIV were $6.3 \%(95 \% \mathrm{Cl} 2.9-10.3)$ and 6.9 (95\% Cl 5.2-11.3), respectively. Histories of scarification (62.1\%), multiple sex partners (31.0\%) and sexually transmitted diseases (66.1\%) were the most common risk factors of HCV transmission in this study.
\end{abstract}

Keywords: Hepatitis C virus, Risk factor, Human immunodeficiency virus, Co-infection, Rural Cameroon

\section{Introduction}

Both hepatitis $\mathrm{C}$ virus (HCV) and the human immunodeficiency virus (HIV) are major public health concerns worldwide due to their high prevalences, morbidity and mortality. This is aggravated by the co-infection with both viruses, as one accelerates the course of the other [1-4].

The hepatitis $C$ virus is a major cause of chronic liver disease, and a leading cause of non-AIDS related death among persons infected with HIV in sub-Saharan Africa [5-7]. Since the introduction of highly active antiretroviral therapy, a decline in the mortality in HIV-infected persons from opportunistic infections has been observed; in contrast, there has been a significant increase in morbidity and mortality of HIV-infected persons related to HCV infection [2, 5].

Globally, 20-30\% of the 34 million persons living with HIV/AIDS are co-infected with HCV [8]. According to WHO, Africa bears the highest prevalence of chronic HCV of 5.3\% [9]. The prevalence of chronic hepatitis C

\footnotetext{
*Correspondence: nvagbor@gmail.com

${ }^{1}$ Faculty of Medicine and Biomedical Sciences (FMBS), The University of Yaoundé I, Yaoundé, Cameroon

Full list of author information is available at the end of the article
}

in Cameroon is estimated to about $13 \%$ [10]. The prevalence of $\mathrm{HCV}$ in Cameroon varies widely between 12.5 and $23.9 \%$ depending on the study population [11-13]. A national prevalence of HIV of 4.3\% was observed in 2011, with the general population of southern Cameroon displaying the highest prevalence of HIV of $10.6 \%$ [14].

The prevalence of HCV/HIV co-infection varies between 0.0 and $7.2 \%$ among the different Cameroonian population [15-17]. Only a single study has evaluated the prevalence of HCV and HIV co-infection among the rural population [15]. With the aim of contributing to the body of knowledge on this area in Cameroon, we carried out this study to evaluate the magnitude of $\mathrm{HCV} / \mathrm{HIV}$ co-infection in a rural community in the South Region of Cameroon.

\section{Main text \\ Study design, duration and setting}

This was a population-based descriptive cross-sectional study conducted from November 2014 and April 2015. Participants were consecutively recruited from Abang Minko'o; a rural community of about 4000 inhabitants in the South Region of Cameroon, along its border with Gabon. All consenting participants aged $\geq 12$ years, who 
were resident in Abang Minko'o for at least 3 months prior to our study were included.

Serological testing was done in the field sites at Abang Minko'o and confirmed in the haematology laboratory of the Yaoundé University Teaching Hospital (YUTH) and the virology laboratory of the Centre Pasteur du Cameroun (CPC)-Yaoundé.

\section{Data collection and management}

After informed consent was obtained, data for each participant was collected unto a pre-structured questionnaire in a private setting and a code was attributed to each participant. In order to describe the seroprevalence of HCV in our study population, data was obtained on the sociodemographic parameter (age, gender, marital status and occupation) of the study participants. Data on the following risk factors for hepatitis $\mathrm{C}$ transmission were collected: parenteral risks (blood transfusion and history of invasive procedures such as: minor surgery, dilatation and curettage, tooth extraction and intravenous drug use), sexual behaviour (number of lifetime sexual partners and history of sexually transmitted disease) and community acquired risk factors (scarification and tattooing in unsanitary facilities). Multiple sex partners were defined as at least three lifetime sex partners.

Five millilitres of blood was collected by venipuncture into ethylene diamine tetraacetate-containing tubes, each carrying a participant code, respecting aseptic rules. Part of the sample was used to carry out the screening tests for HIV and HCV, and the rest stored in an insulated box containing ice packs until transported to Yaoundé for further analysis.

\section{Serological analysis}

All blood samples were screened for HIV at the recruitment site using the rapid test DETERMINE ${ }^{\circledR}$ HIV1/2 ${ }^{\mathrm{a}}$ (Alere; Bedfordview, South Africa) and then IMMUNOCOMB $^{\circledR}$ II HIV $1 \& 2$ BiSpot (Organics, Yavne, Israel) for viral typing if the former was positive. All samples were retested using MUREX HIV Ag/Ab Combo ${ }^{a}$ (DiaSorin; Saluggia, Italy), a third generation Enzyme Linked Immunosorbent Assay (ELISA) technique, at the Haematology laboratory of the YUTH. A sample was considered positive for HIV if either the ELISA or both the ELISA and rapid tests were positive. Samples with a negative ELISA results, regardless of the outcome of the rapid tests, were considered negative.

All samples were also screened for the presence of anti$\mathrm{HCV}$ antibodies using the rapid test IMMUNOCOMB ${ }^{\circledR}$ II HCV (Organics, Yavne, Israel). All positive and indeterminate anti-HCV antibody samples were further retested using the Architect anti-HCV qualitative assay (Abbott, Wiesbaden, Germany), a third generation
Chemiluminescent Microparticle immunoassay (CMIA), at the virology laboratory of the CPC. Samples with either a positive CMIA, or a positive rapid test and CMIA were considered positive for the presence of antihepatitis $\mathrm{C}$ antibodies.

\section{Statistical analysis}

Data was then entered into and analysed with the statistical package for social sciences v20.0. Results were presented as means and medians with their corresponding standard deviations (SD) and interquartile ranges (IQR) for quantitative variables, while for qualitative variables, results were presented as frequencies, proportions and bar charts.

\section{Results}

A total of 174 participants were included in this study. The female prevalence was $46.6 \%$. The mean and median ages of our study participants was $30.12(\mathrm{SD}=13.26)$ and 28.0 (IQR $=19.75-37.0)$ years, respectively. Participants ages ranged from 12 to 77 years. The $16-25$ years age group was the most represented (31\%). Half (52\%) of the participants were single, $33 \%$ were married, meanwhile $15 \%$ of them were cohabiting, Table 1.

As shown in Table 1, eleven out of the 174 study participants tested positive for the presence of anti-HCV antibodies, giving an overall prevalence of $6.3 \%$ (95\% CI $2.9-10.3), 53.4 \%$ of who were males. Also shows the distribution of anti-HCV antibodies among the different sociodemographic characteristics. Self-employed participants displayed the highest proportion of anti-HCV antibodies (34.5\%), followed by students $(28.2 \%)$, and then farmers (16.7\%). Participants within 46-55 years age group had the highest group prevalence of anti-HCV antibodies followed by the age groups 56 years and over and 15 years and below, Table 1.

Figure 1 depicts the proportion of the different risk factors of hepatitis $\mathrm{C}$ in our study population. Histories of multiple sexual partners (66.1\%), scarification (62.1\%) and sexually transmitted diseases $(31.0 \%)$ were the most common risk factors in this population. Meanwhile, Histories of non-medicalised tattooing (3.4\%) and blood transfusion (7.5\%) were rare. No participant reported illicit intravenous drug use.

Of the 174 participants, 12 were confirmed HIV positive. Hence, an HIV prevalence of 6.9\% (95\% CI 5.2-11.3). A greater proportion of females (7.4\%) were infected compared to males $(6.5 \%)$. The $16-35$ age group represented $50 \%$ of the infected cases, Table 2 . The prevalence of HIV among the reproductive age group (15-49 years) was $6.4 \%$. All samples tested positive for HIV type 1.

Finally, a dual infection was noted in 3 of the 174 participants giving a co-infection rate of $1.7 \%$. 
Table 1 Distribution of HCV seropositivity with sociodemographic characteristics, Abang Minko'o 2015

\begin{tabular}{|c|c|c|}
\hline Characteristics & $n(\%)[N=174]$ & $\begin{array}{l}\mathrm{HCV}+\text { cases } \\
(\%)[\mathrm{N}=11]\end{array}$ \\
\hline \multicolumn{3}{|l|}{ Gender } \\
\hline Male & $93(53.4)$ & $6(54.5)$ \\
\hline Female & 81 (46.6) & $5(45.5)$ \\
\hline \multicolumn{3}{|l|}{ Age group } \\
\hline$[\leq 15]$ & $20(11.5)$ & $2(18.2)$ \\
\hline [16-25] & 55 (31.6) & $2(18.2)$ \\
\hline [26-35] & 48 (27.6) & $1(9.1)$ \\
\hline [36-45] & $31(17.8)$ & $2(18.2)$ \\
\hline$[46-55]$ & $14(8.0)$ & $3(27.3)$ \\
\hline$[\geq 56]$ & $6(3.4)$ & $1(9.1)$ \\
\hline \multicolumn{3}{|l|}{ Marital status } \\
\hline Married & $57(32.8)$ & $5(45.5)$ \\
\hline Single & $90(51.7)$ & $6(54.5)$ \\
\hline Cohabiting & $27(15.5)$ & $0(0.0)$ \\
\hline \multicolumn{3}{|l|}{ Occupation } \\
\hline Civil servant & 19 (10.9) & $2(18.2)$ \\
\hline Farming & $29(16.7)$ & $1(9.1)$ \\
\hline Self-employed & $60(34.5)$ & $1(9.1)$ \\
\hline Student & $49(28.2)$ & $5(45.5)$ \\
\hline Unemployed & $11(6.3)$ & $1(9.1)$ \\
\hline Others & $6(3.4)$ & $1(9.1)$ \\
\hline
\end{tabular}

$n$ number of participants in each category/subcategory, $N$ total number of participants

\section{Discussion}

Herein, we report the prevalence of $\mathrm{HCV}$ was $6.3 \%$. The commonest risk factors for hepatitis $\mathrm{C}$ transmission were histories of multiple sex partners, scarification and sexually transmitted diseases. Finally, the prevalence of $\mathrm{HCV}$ and HIV co-infection was $1.7 \%$.

The seroprevalence of $\mathrm{HCV}$ in our study population was $6.3 \%$ is comparable to the prevalence of 6.4 and $6.9 \%$ reported by Ndumbe et al. [11] and Nerrienet et al. [18] in Cameroon. These results which are similar support the fact that Cameroon is an area where $\mathrm{HCV}$ is highly endemic. Also, similar prevalences of $\mathrm{HCV} ; 6.0 \%$ by Hadush et al. [19] and $5.4 \%$ by Simpore et al. [20] have been reported from other sub-Sahara African countries. However, controversial prevalences have been reported by other local research works [12, 13, 18, 21]. The discrepancies in these results could be as a result of a difference in size and risk factors of $\mathrm{HCV}$ transmission between sample population, study methodology and geographical differences. Transmission rates vary depending on the stage of the infection, age, risk group, exposure, diagnosis status and treatment status [22]. The relatively low prevalence of blood transfusion and invasive procedures such as tattooing in non-medicalised facilities and history of dilatation and curettage, and the non-existence of intravenous drug users in our study population could explain the lower seroprevalence of $\mathrm{HCV}$ observed in this study. Indeed, the transmission of $\mathrm{HCV}$ through blood route during blood transfusion and invasive procedures

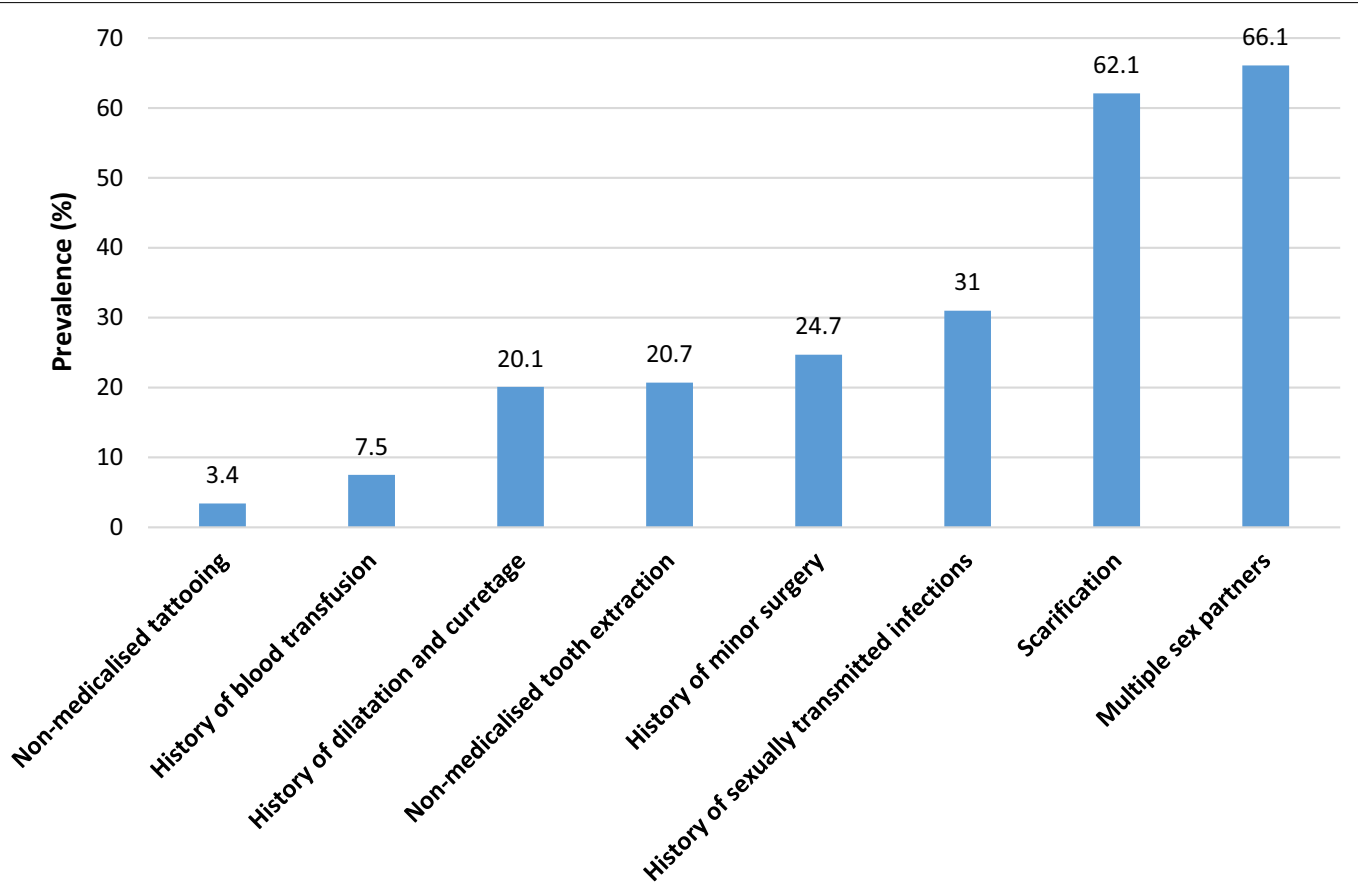

Fig. 1 Prevalence of risk factors for hepatitis C transmission in our study population, Abang Minko 2015 
Table 2 Distribution of HIV among the different age groups, Abang Minko'o, 2015

\begin{tabular}{|c|c|c|c|c|c|c|c|}
\hline Age group (years) & {$[\leq 15]$} & [16-25] & [26-35] & [36-45] & [46-55] & {$[\geq 56]$} & Total \\
\hline $\mathrm{HIV}+(\mathrm{n}=12)^{\mathrm{a}}$ & 1 & 2 & 4 & 2 & 3 & 0 & 12 \\
\hline Number of participants & 20 & 54 & 47 & 32 & 15 & 6 & 174 \\
\hline Prevalence $(\%)^{\mathrm{b}}$ & 5.0 & 3.7 & 8.5 & 6.2 & 20 & 0 & 6.9 \\
\hline Infected cases $(\%)^{c}$ & 8.3 & 16.7 & 33.3 & 16.7 & 25.0 & 0 & 100.0 \\
\hline
\end{tabular}

HIV human immunodeficiency virus

a Number of positive HIV cases

b Age group prevalence

c Percentage of infected cases

has been associated with the greatest risk of hepatitis $\mathrm{C}$ transmission [23].

The $6.9 \%$ prevalence rate of HIV in this study is similar to the $7.4 \%$ prevalence reported in the East Region of Cameroon [15]. Other research works carried out in Cameroon have shown varying HIV prevalences. Higher prevalences of $10.7 \%$ in the Southwest Region [24], and 10.6 and $8.6 \%$ in the South Region and Yaoundé respectively [14]. Also, our finding was greater than the prevalence of HIV in the general Cameroonian population [14]. A higher prevalence of HIV infection was observed for females $(7.4 \%)$ than for males $(6.5 \%)$. This was consistent with the 2011 report of the national demographic and health survey conducted in Cameroon, whereby a higher prevalence of HIV was noted in females compared to males [14]. These results which are comparable support the fact that women are more vulnerable to HIV infection than men. Cultural factors, economical dependence of women on men and poor access to education and healthcare go a long way to explain why the African woman in general and Cameroonian woman in particular is susceptible to HIV [25].

The seroprevalence of HCV and HIV co-infection was 1.7\%. Similar results have been reported by Laurent et al. from Cameroon [15] and other African authors; $1.6 \%$ by Hadush et al. from Ethiopia [19], $1.7 \%$ by Mboto et al. from Gambia [26], 1.86\% by Onakewhor et al. from Nigeria [27] and 1.9\% by Amin et al. from South Africa [28]. Even with the high prevalence of HCV and HIV, and of risky sexual behaviours, the co-infection rate between these two viruses in the general population was low. Sexual intercourse is the main route of transmission of HIV $[15,24]$, while blood is the main route of transmission of HCV [23]. These findings could suggest that sexual transmission of $\mathrm{HCV}$ is not a predominant route of transmission, but given the small sample size, this cannot be generalized. Indeed, there has been some controversies about the sexual transmission of $\mathrm{HCV}[9,29]$.

\section{Conclusion}

The prevalence of the co-infection of HCV with HIV in the study population is low. However, we noted a high seroprevalence of HCV and HIV infections. The history of multiple sex partners, scarification and sexually transmitted diseases were the most common risk factors for HCV infection in this population. Similar studies with larger sample sizes are needed in other regions to better understand the prevalence of $\mathrm{HCV}$ and HIV co-infection and the risk factors for $\mathrm{HCV}$ transmission. Public health programs aimed at educating and encouraging safe sexual behaviours in this rural community are recommended. Education on the health risks of cultural scarification practices is highly endorsed.

\section{Study limitations}

The findings in herein should be interpreted in the context of the study limitations. Although we used very reliable methods for the diagnosis of HIV and $\mathrm{HCV}$, a confirmatory assay is usually recommended. Also, our findings cannot be generalised to the South Region of Cameroon due to a small sample size and unequal representation of all age groups. Data on the risk factors of $\mathrm{HCV}$ in this study were subject to a recollection bias as it depended mostly on the ability of the participants to remember whether they had been exposed to the risk factor or not.

\section{Abbreviations \\ CPC: Centre Pasteur du Cameroun; HIV: human immunodeficiency virus; HCV: hepatitis C virus; YUTH: Yaoundé University Teaching Hospital.

\begin{abstract}
Authors' contributions
Study design: VNA, CTT, DM and NN. Drafting of study protocol: VNA, CTT, DM and NN. Sample collection and laboratory analysis: VNA, JBK, BA and CN. Statistical analysis and interpretation of results: VNA, CTT, DM and NN. Drafting of the initial manuscript: VNA, CTT, DM and NN. Revision of the manuscript: VNA, CTT, JBK, BA, CN, DM and NN. All authors read and approved the final
\end{abstract} manuscript.}

\footnotetext{
Author details

${ }^{1}$ Faculty of Medicine and Biomedical Sciences (FMBS), The University

of Yaoundé I, Yaoundé, Cameroon. ${ }^{2}$ Yaoundé University Teaching Hospital
} 
(YUTH), Yaoundé, Cameroon. ${ }^{3}$ Society for Women and AIDS in Africa (SWAA), Yaoundé, Cameroon. ${ }^{4}$ Institute of Human Virology Nigeria, Abuja, Nigeria.

\section{Acknowledgements}

The authors will like to acknowledge the Director General of the Yaoundé University Teaching Hospital and the Centre Pasteur du Cameroun for authorisations to carry out work in their institutions, as well as the staff of both structures for their support in sample storage and analysis. Also, we are grateful to Dr. Yvonne N. Fonweban for her invaluable assistance during sample collection and laboratory analysis. Finally, the authors will like to extend their sincere gratitude to the participants who took part in the study.

\section{Competing interests}

The authors declare that they have no competing interests.

\section{Availability of data and materials}

The datasets for this study is available from the corresponding author on reasonable request.

\section{Consent for publication}

Not applicable

\section{Ethics approval and consent to participate}

Recruitment of study participants and serologic testing were effectuated only after ethical approval of the study protocol by Ethical review board of the Faculty of Medicine and Biomedical Sciences, University of Yaoundé I, Yaoundé, Cameroon. Administrative authorisations were obtained from the Regional Delegation for Health for the South Region and Director General of the Yaoundé University Teaching Hospital and The Centre Pasteur du Cameroun. All of our study participants were either English- or French-speaking. According to the language of choice (English or French), all participants were duly informed of the details of the study and were required to each sign a consent form after full understanding of the project. Children from 18 years and below needed approval from a parent or guardian to be enrolled into the study. A pre-structured questionnaire was completed for each participant and each was attributed a code for confidentiality and identification. Only those who gave an informed consent were enrolled in this study. All questionings, counselling and delivery of results were conducted in set-ups that guaranteed maximum privacy and all results were coded for confidentiality. The participants, as desired, were all informed of their HIV screening results after a post-test counselling. All HCV and/or HIV infected participants were referred to the nearest certified treatment centre for better management.

\section{Funding}

The process of sample collection to sample analysis was funded by the Viral Discovery Project and assisted by the Society for Women and AIDS in Africa (SWAA)-Cameroon.

\section{Publisher's Note}

Springer Nature remains neutral with regard to jurisdictional claims in published maps and institutional affiliations.

Received: 15 May 2018 Accepted: 5 July 2018

Published online: 11 July 2018

\section{References}

1. Mohsen AH, Easterbrook P, Taylor CB, Norris S. Hepatitis C and HIV-1 coinfection. Gut. 2002;51:601

2. Loko MA, Bani-Sadr F, Winnock M, Lacombe K, Carrieri P, Neau D, et al. Impact of HAART exposure and associated lipodystrophy on advanced liver fibrosis in HIV/HCV-coinfected patients. J Viral Hepat. 2011;18:e307-14.

3. Benhamou Y, Bochet M, Di Martino V, Charlotte F, Azria F, Coutellier A, et al. Liver fibrosis progression in human immunodeficiency virus and hepatitis C virus coinfected patients. The Multivirc Group. Hepatology 1999:30:1054-8.

4. Seeff LB. Natural history of chronic hepatitis C. Hepatology. 2002;36(5 Suppl 1):S35-46.
5. Price JC, Thio CL. Liver disease in the HIV-infected individual. Clin Gastroenterol Hepatol. 2010;8:1002-12.

6. Data Collection on Adverse Events of Anti-HIV drugs (D:A:D) Study Group, Smith C, Sabin CA, Lundgren JD, Thiebaut R, Weber R, et al. Factors associated with specific causes of death amongst HIV-positive individuals in the D:A: D Study. AIDS. 2010;24:1537-48.

7. Bica I, McGovern B, Dhar R, Stone D, McGowan K, Scheib R, et al. Increasing mortality due to end-stage liver disease in patients with human immunodeficiency virus infection. Clin Infect Dis. 2001;32:492-7.

8. Webster DP, Klenerman P, Dusheiko GM. Lancet seminar-hepatitis C. Lancet. 2015:385:1124-35.

9. Karoney MJ, Siika AM. Hepatitis C virus (HCV) infection in Africa: a review. Pan Afr Med J. 2013. https://doi.org/10.11604/ pamj.2013.14.44.2199.

10. WHO. Guidelines for screening and treatment of persons with hepatitis $C$ infection. Geneva: World Health Organisation; 2014. p. 121.

11. Ndumbe P, Skalsky J. Hepatitis $C$ virus infection in different populations in Cameroon. Virus Immunol. 1993;25:689-92.

12. Kowo M, Goubau P, Ndam E. Prevalence of hepatitis $C$ virus and other blood-borne viruses in Pygmies and neighbouring Bantus in southern Cameroon. Trans R Soc Trop Med Hyg. 1995;89:484-6.

13. Kemmegne J, Mbanya D, Loius F. Seropositivité vis-à-vis du virus de I'hepatite C chez les drepaocytaires polytransfusés à Yaoundé, Cameroun. Médecine Tropicale. 1996;56:309-10.

14. Institute Nationale de la Statistique, International ICF. Cameroun Enquête Démographique et de Santé et à Indicateurs Multiples (EDS-MICS) 2011; 2012. http://dhsprogram.com/publications/publication-fr260-dhs-final -reports.cfm. Accessed 21 Jun 2016.

15. Laurent C, Bourgeois A, Mpoudi M, Butel C, Mpoudi-Ngolé E, Delaporte E. HIV and hepatitis $C$ virus coinfection, Cameroon. Emerg Infect Dis. 2007;13:514-6.

16. Eboumbou Moukoko CE, Ngo Sack F, Essangui Same EG, Mbangue M, Lehman LG. HIV, HBV, HCV and T. pallidum infections among blood donors and Transfusion-related complications among recipients at the Laquintinie hospital in Douala, Cameroon. BMC Hematol. 2014;14:5.

17. Noubiap JJN, Aka PV, Nanfack AJ, Agyingi LA, Ngai JN, Nyambi PN. Hepatitis B and C co-infections in some HIV-positive populations in Cameroon, West Central Africa: analysis of samples collected over more than a decade. PLoS ONE. 2015:10:e0137375.

18. Nerienet E, Pouillot R, Lachenal G, Njouom R, Mfoupouendoun J, Bilong C, et al. 13. Hepatitis C virus infection in Cameroon: a cohort-effect. J Med Virol. 2005;76:208-14

19. Hadush H, Gebre-Selassie S, Mihret A. Hepatitis C virus and human immunodeficiency virus coinfection among attendants of voluntary counseling and testing centre and HIV follow up clinics in Mekelle Hospital. Pan Afr Med J. 2013. https://doi.org/10.11604/pamj.2013.14.107.2302.

20. Simpore J, Savadogo A, Ilboudo D, Nadambega MC, Esposito M, Yara J, et al. Toxoplasma gondii, HCV, and HBV seroprevalence and co-infection among HIV-positive and -negative pregnant women in Burkina Faso. J Med Virol. 2006:78:730-3.

21. Mbanya D, Ndumbe P. Serological findings amongst first-time blood donors in Yaounde, Cameroon: is safe donation a reality or a myth? Transf Med. 2003;13:267-73.

22. Madhava V, Burgess $C$, Drucker E. Epidemiology of chronic hepatitis C virus infection in sub-Saharan Africa. Lancet Infect Dis. 2002;2:293-302.

23. Murray K, Richardson L, Morishima C. 10. Prevalence of hepatitis C virus infection and risk factors in an incarcerated juvenile population: a pilot study. Pediatrics. 2003;111:153-7.

24. Shevell L, Meriki HD, Cho-Ngwa F, Fuller C. Epidemiology of human immunodeficiency virus-1 and hepatitis B virus co-infection and risk factors for acquiring these infections in the Fako division of Southwest Cameroon. BMC Public Health. 2015. https://doi.org/10.1186/s1288 9-015-2386-x

25. Mbanya D, Sama M, Tchounwou P. Current status of HIV/AIDS in Cameroon: how effective are control strategies? Int J Environ Res Public Health. 2008;5:378-83.

26. Mboto $\mathrm{Cl}$, Fielder $\mathrm{M}$, Davies-Russell $\mathrm{A}$, Jewell AP. Prevalence of HIV-1, HIV-2, hepatitis C and co-infection in the Gambia. West Afr J Med. 2009;28:16-9. 
27. Onakewhor JUE, Okonofua FE. The prevalence of dual human immunodeficiency virus/hepatitis C virus (HIV/HCV) infection in asymptomatic pregnant women in Benin City. Nigeria. Afr J Reprod Health. 2009. https:// doi.org/10.4314/ajrh.v13i2.55709.

28. Amin J, Kaye M, Skidmore S, Pillay D, Cooper DA, Dore GJ. HIV and hepatitis C coinfection within the CAESAR study. HIV Med. 2004;5:174-9.
29. Bellentani S, Pozzato G, Saccoccio G, Crovatto M, Crocè LS, Mazzoran $L$, et al. Clinical course and risk factors of hepatitis $C$ virus related liver disease in the general population: report from the Dionysos study. Gut. 1999:44:874-80.
Ready to submit your research? Choose BMC and benefit from:

- fast, convenient online submission

- thorough peer review by experienced researchers in your field

- rapid publication on acceptance

- support for research data, including large and complex data types

- gold Open Access which fosters wider collaboration and increased citations

- maximum visibility for your research: over $100 \mathrm{M}$ website views per year

At BMC, research is always in progress.

Learn more biomedcentral.com/submissions 